\title{
(Re) Evolution in HR Strategies - Power Sector
}

\author{
Y. P. Chawla \\ Advisor, Tariff- Jt. Elec. Regu. Commn., National Jt. Secretary IIPE
}

\begin{abstract}
Evolution or a revolution in HR Strategies is required in the vibrant and expanding Powerful Sector. The power Sector in India has gone in for reforms unbundling the sector into separate accountable entities. The Power Sector conventionally revolves around Power Generation, Transmission and Distribution. The Manufacturing (or Sourcing from Manufacturers) and Project Development is as much important from the developers' perspective. Each of these activities requires specialized skill sets. In this paper, emphasis has been placed on Supercritical Thermal Power Plants.

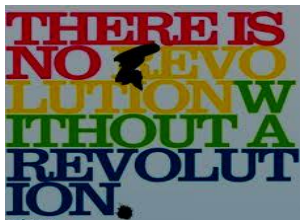

The HR Managers, if are passive are just to pass on the job description to HR Consultant, but the active ones will get involved with the process of Placement and or pre-placement training for having a human resource added to the organization. Some of the organizations in any of the above activities of the Power Sector are even considering $H R$ department as a profit center. As a business transformation of the Power Sector organization, the HR Skill center goes on developing number of personnel, the best ones are picked up by their own organization, and the others are made available to the sub-contractors or other organizations. In both cases HR Skill center acts as a placement company specializing in Power Sector. While Power sector needs skilled manpower at home, there is an acute shortage to run the Power Plants abroad. Power Sector personnel are getting re-employed to meet the partial shortage.

The Skills mismatch and skill gaps are being now heard in every sector and Power Sector is not different. This is more acute in Europe where the work force is becoming grey. Even China is on the edge to suffer because of One Child Policy. New business models like Cross Culture Joint Ventures (JVs), Public Private Partnership (PPP) involve a lot of vibrations in complete HR Chain.
\end{abstract}

Key Words: Power Sector, HR Strategies, Re-Evolution, Shortage of Skilled Manpower, HR as Profit Center.

\section{Mismatch of Skill Availability \& the Requirements - A 'HR Challenge'}

Mismatch in the Educational or Vocational Training Curriculum and the needs of the Power Sector set for an explosive growth Industry are posing a new challenge in inducting fresh manpower for the Organization's expansion programs or entry into Power Sector. The Power Sector is evolving new technologies for higher productive, more automated, more IT based, leaves big gaps in the requirements. The Power Sector has traditionally been using on the job training after a small induction orientation program. There is a skill gap even for re-employed (experienced) manpower, if they have not kept themselves updated.

To meet the skilled manpower shortages, employers have taken initiative not to let the mature workers be a neglected Human Resource for meeting the Organization's needs and increasing productivity. The Council for Adult and Experiential Learning (CAEL) and the Council on Competitiveness (CoC), both these organizations in US which specialize in adult learning and economic competitiveness, have joined together in this regard.

\section{Returns on Skilling Investment - A parameter of Efficiency of HRM's efforts}

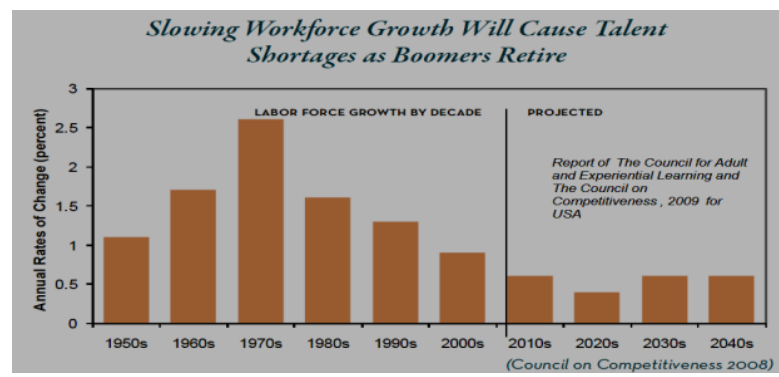

Aspen Institute studies - USA indicate that the growth in educated workers slowing from 19 percent during 2 decades 1980 to 2000 to 4 percent in next 2 decades (Ellwood 2002).

Return on Investment - ROI (considering HR department to be a department giving Skilled Manpower as Input) has been analyzed for various parameters and Increased Retention initiative has been rated as the best ROI in a study in USA.

Vocational Programs for Power Sector: The Power Sector Skilled Manpower needs cover Vocational jobs which are in great shortage. The ITIs \& ITCs lack the training infrastructure to match the fast changing Industry requirements. The sluggish government Infrastructure by the time, it thinks to upgrade any training facility by a notch, the Industry requirements quite often would have gone up by 3-4 notches. 
(Re) Evolution in HR Strategies - Power Sector

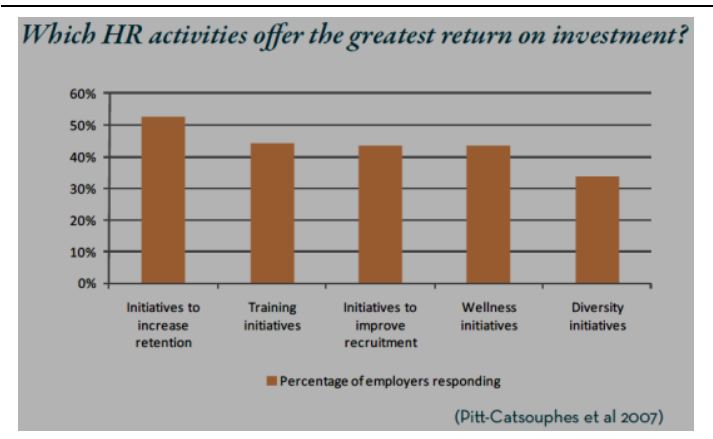

The Vocational Education has gained focus and importance in India and in every country linked to the Global Economy thus creating a need for modular, lifelong learning for bluecollar workers, which is a life-long job for HR team. Power Sector Industry has set up its own training centers or have picked up ITIs to be able to run for meeting its requirements. Jindal Steel \& Power, Reliance Power, NTPC are a few to be named for such an initiative. Accreditation of these programs can be arranged by IGNOU distance learning programs (to be discussed and approved), Sectoral Skill Councils (like Welding), Construction Council (a similar one for Power Sector is under development). Vocationally Skilled man power is becoming "Hard to fill Jobs" across the globe.

\section{Technology Related Skill Gaps:}

"Technology related skill gaps (if not corrected) will damage the Indian Economy - Studies warn. Studies also conclude $75 \%$ of Technical Graduates \& $85 \%$ of General Graduates are Unemployable by India's High Growth Global Industries, unless Skills are added (The Wall Street Journal) and India Aspires to be a Knowledge Superpower. In Asia Pacific market Employers (45\%) facing difficulty in Job filling because of Lack of Available Talent (Talent Shortage Survey 2011). Indian has to take fast action on taking advantage of its demographic strength which is $>50 \%$ Population $<35$ Yrs. Power Sector need totally Technology Based skills.

Not only Power Sector, it is every sector of the economy in India is feeling the heat of global slowdown and Interest Rates not conducing to good returns from Business. However, the business of Skill development and higher education is the one that is growing globally. The Skills are said to be new global currency soon. The Counties with higher strength of skilled Manpower will earn more remittances from abroad and is going to develop faster than other Countries with lesser Skilled Manpower. This is because higher Skill sets and education is linked with the aspirations of people. This gives a Philip to HR team to develop personnel.

\section{Parameters of Power Sector Skills:}

1. A Highly Labour Efficient Sector in Manufacturing Electrical Machinery: as per the BCG Report on Manufacturing. It is highly automated.
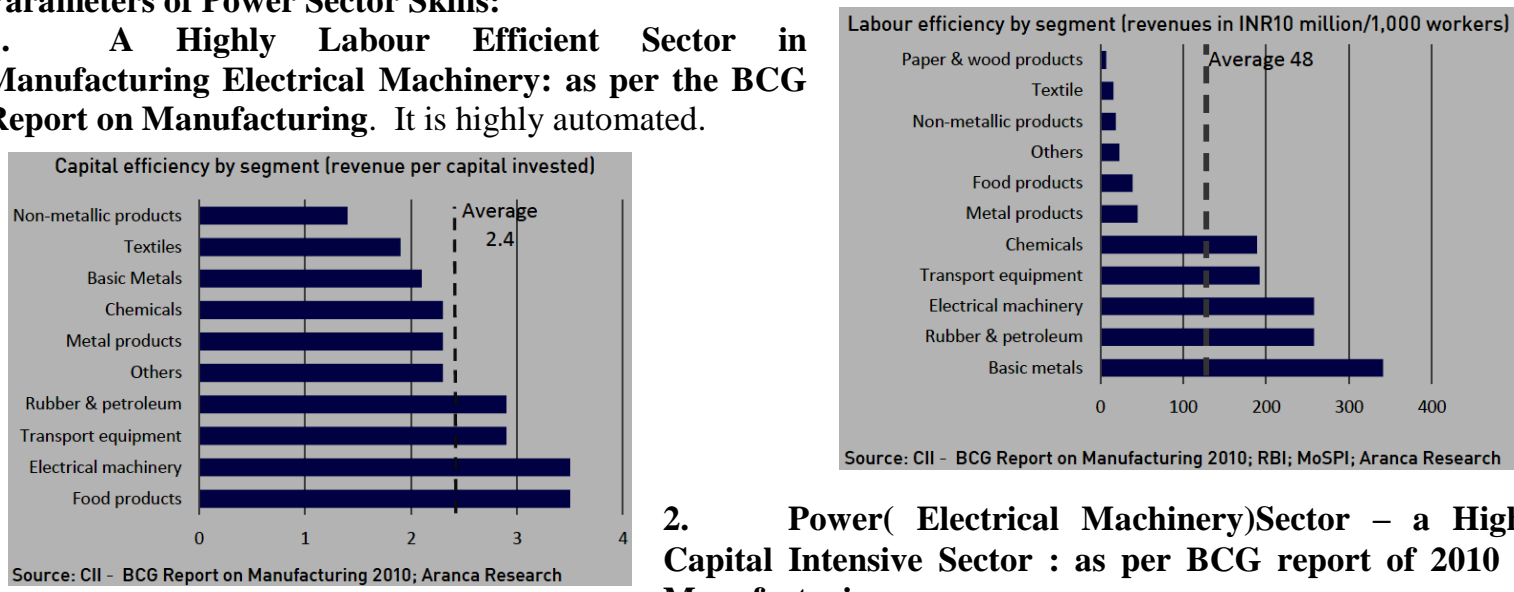

2. Power( Electrical Machinery)Sector - a Highly Capital Intensive Sector : as per BCG report of 2010 on Manufacturing

3. Power ( Electrical Machinery) Sector - a low labour intensive sector, because of more automation As per CII- BCG Report on Manufacturing of 2010

Low Skilled jobs are by contractual workers or by sub-contractors. In interaction with a manufacturing company

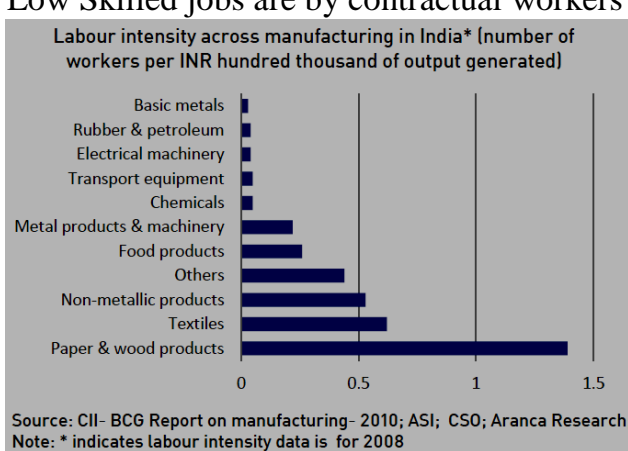
getting into new manufacturing of Power sector, the information is Engineers are directly into manufacturing on automated machines than vocationally trained Technicians.

\section{Soft Skill Requirements:}

In the last few years, the number of Skill development Institutes, Engineering colleges, business schools and enrolments has gone up in India. There is demand \& Supply gap felt in the power sector whether by the people and industry and yet Industry is not getting what they require in terms of qualitative inputs Industry requires from the new entrants to the Industry. 
Soft Skills Inventory (major):

The HR Team in addition to Power Sector needed skills have also to focus on

Communication skills - ability to effectively communicate and productively contribute in developing an Harmonious environment in the organization and also with the customers

Lifelong learning (LLL) - For fast technological change and expansion plans of the Organisation, willingness to continuously learn,

Problem solving - Managing information capability, provide support through documentation appropriate for the official requirement and knowledge of contemporary developments, identifying problems and suggesting solutions

Professionalism - Appreciating and remaining committed to professional, social and ethical responsibilities, observing professional discipline and considerate about the impact of workplace on local and global context.

Teamwork - ability to function in multidisciplinary and multicultural teams as member/leader and promote dynamic working relationships and outcomes.

Updating oneself - Self Learning: the ability to keep on updating through web is a provider of the latest practices that might be productive for one's work place

\section{Challenges for HR team in Power Sector}

The Challenge of HR Team is many folds and most demanding. Technically trained manpower comprising of skilled engineers, supervisors, artisans, and managers etc. is required in every sphere of the power sector. Growing concern over environmental degradation and depletion of the conventional energy sources has made the task of electricity generation even more challenging and therefore quality standard of the manpower is becoming increasingly essential. The Power is being traded at a margin of 1 paise / Kwh (unit), which implies that every activity in power generation has to be most productive and innovative to beat the competition.

In India a Thermal Power Plant needs to cross about 65 Steps (some experts club it to 40 steps), from Project acquisition, to land acquisition to various clearances at State and Center's level etc. The top management's needs to get these activities through HR selected personnel or their own select few. With 88 Sets of 800 / $660 \mathrm{MW}, 85$ sets of 500/ 250 / $200 \mathrm{MW}$ in addition to a similar number of the same rating, task is mammoth. The relevant extracts from the Working group report of Planning Commission on Power Sector dated Jan 2012 spells very clearly :

\section{Quote}

\section{"Ensure Availability / Development of skilled manpower}

The availability of skilled and semi-skilled manpower for project execution has been an area of concern. Both the developer and the contractor(s) have to jointly make efforts for providing training and necessary skill sets to local people to improve their employability "

\section{Adoption of latest techniques in project execution} be adopted.

Latest methods of civil construction with mechanized equipment and manpower mobilization needs to

\section{Construction Techniques}

Latest methods of civil construction with mechanized equipment and manpower mobilization needs to be adopted. Vendors should be encouraged to adopt new erection technologies to reduce the erection and commissioning cycle.

\section{Bridging skill gaps}

Industry is facing severe shortage of skilled manpower like welders (especially High Pressure

welders), fitters, turners, masons, carpenters etc.

Following is recommended:

(i) Creation of adequate number of new modern technical training institutions under government sector and facilitation in creation of the same under private sector.

(ii) PPE manufacturers and Developers will have to take a lead in Training and skill enhancement of manpower through encouragement and facilitation of plant visits to live projects, internship, guest lectures and other means of industry interaction with students and faculty of technical institutions. 
(iii) An institutional mechanism for setting up Regional Skill Development Centers by pooling resources from Power Developers, Manufacturers and Contractors to enable a substantial increase in the availability of trained and skilled manpower. "

\section{Unquote}

The HRM's work quantum changes drastically depending on the work philosophy of the management in deciding how the balance of plant (BOP) procurement models viz. General Civil Works + BOP of Plant or split into Mechanical BOP \& Electrical BoP and may be C\&I-BoP separately. 100 BoP Packages in Mudra TPS by Tata's and only 14 BoP Packages for its Maithan Project changes man power requirements. The Manpower requirements change qualitatively \& quantitatively in both approaches. This manpower requirement will get reflected in the BoP Contractor's scope. Similarly R\&M as well as some parts of O\&M by the company own personnel or Sub Contractor's personnel will change the man power requirement from one company to another company and micro level monitoring at one end or other.

The role of HR may start at the beginning, when the Project idea is conceived or may be at a, later stage. A few of the organization picked up tabs on a few individuals expecting to start the Project soon with a hope to get Coal Linkages in India or Coal Mine deal abroad have been paying for them over 3-4 Years now, similar to a few who have been hired in anticipation for Nuclear Projects.

Talent Shortage a Global Phenomenon:

Even abroad the Skill Shortage makes them employ foreign talent as under:

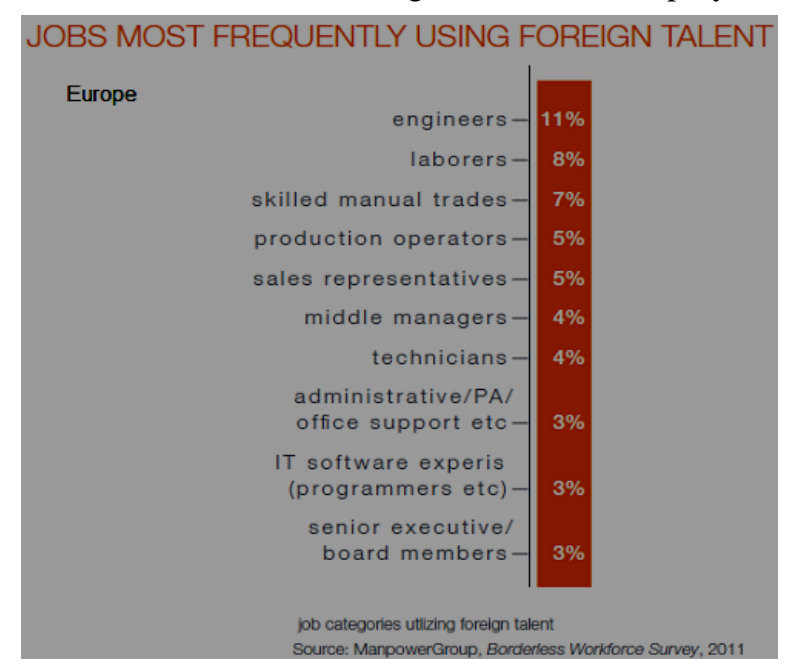

\begin{tabular}{|c|c|}
\hline \multicolumn{2}{|c|}{ JOBS MOST IN DEMAND } \\
\hline 2011 & 2010 \\
\hline Technicians & Skilled Trades \\
\hline Sales Representatives & Sales Representatives \\
\hline Skilled Trades Workers & Technicians \\
\hline Engineers & Engineers \\
\hline Laborers & Accounting \& Finance Staff \\
\hline Management/Executives & Production Operators \\
\hline Accounting \& Finance Staff & Administrative Assistants/PAs \\
\hline IT Staff & Management/Executives \\
\hline Production Operators & Drivers \\
\hline $\begin{array}{l}\text { Secretaries, PAs, Administrative } \\
\text { Assistants \& Office Support Staff }\end{array}$ & Laborers \\
\hline
\end{tabular}

The country is poised to build more power generation capacity as well as supporting power systems in the next 10 years as compared to the previous 30 years. This necessitates induction of significant qualitative quantum of manpower in to the sector. Even though the country produces a large number of new engineers every year, it is not possible to directly deploy them in to the work force without proper training due to the technology intensive nature of the industry. The induction programs currently specified by the CEA range in duration between six to twelve months for engineers, operators, supervisors and technicians based on the technology area. Further, experienced professionals are required for critical activities and it is difficult to augment the number of such professionals in a short period of time. Hence adequate capacity building measures need to be undertaken to ensure the ready availability of manpower required for achieving the plan targets. Further, continuous training should be provided to the current manpower to ensure up-to-date technical skills, higher motivation and productivity. The Overall Skill requirements for various Industries as per CII Study is as under ,Power Sector has been clubbed with the construction Industry

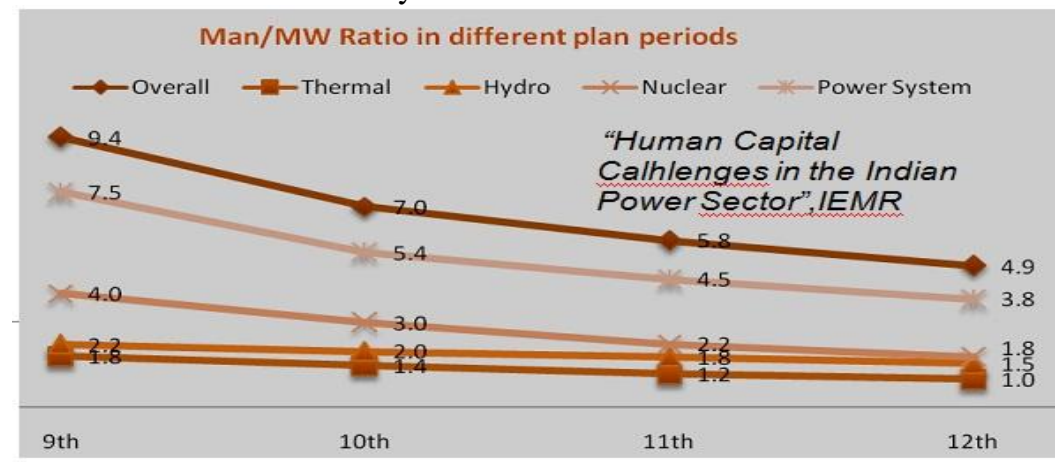

www.iosrjournals.org 
(Re) Evolution in HR Strategies - Power Sector

The Man power requirements in each of the 5 years plan vary marginally between IEMR report and the Working Group report ( set up by Planning Commission) on Power Sector, dated Jan 2012 ,possibly because of variation inputs considered in both the reports. The Planning Commission report depicts Skill gaps \& the manpower requirements as under:

Man/MW Ratio at the end of various Plan Periods

\begin{tabular}{|cccccc|}
\hline End of Plan Period & Thermal & Hydro & Nuclear & Transmission \& Distribution & Overall \\
\hline 9th & 1.78 & 2.20 & 3.97 & 7.50 & 9.42 \\
\hline 10th & 1.44 & 1.95 & 2.96 & 5.41 & 7.00 \\
\hline 11th & 1.08 & 1.74 & 2.27 & 4.37 & 5.63 \\
\hline 12th & 0.85 & 1.56 & 1.87 & 3.73 & 4.74 \\
\hline 13th & 0.72 & 1.43 & 1.59 & 3.34 & 4.23 \\
\hline
\end{tabular}

Manpower under various Plans

Capacity in MW and Man Power in Thousands

\begin{tabular}{|c|c|c|c|c|c|c|c|c|c|}
\hline S No & Plan & $\begin{array}{c}\text { Capacit } \\
\text { y at the } \\
\text { beginni } \\
\text { ng of } \\
\text { Plan }\end{array}$ & $\begin{array}{c}\text { Capacity } \\
\text { addition } \\
\text { during } \\
\text { Plan* }\end{array}$ & $\begin{array}{l}\text { Capacity } \\
\text { at the } \\
\text { end of } \\
\text { Plan }\end{array}$ & $\begin{array}{l}\text { Manpowe } \\
r \text { at the } \\
\text { beginning } \\
\text { of Plan }\end{array}$ & $\begin{array}{l}\text { Reduced } \\
\text { Manpower } \\
\text { due to } \\
\text { retirement } \\
\text { etc. }\end{array}$ & $\begin{array}{l}\text { Manpower } \\
\text { required for } \\
\text { Capacity } \\
\text { addition of } \\
\text { Plan }\end{array}$ & $\begin{array}{l}\text { Manpo } \\
\text { wer at } \\
\text { the end } \\
\text { of Plan }\end{array}$ & $\begin{array}{l}\text { Man/MW } \\
\text { at the end } \\
\text { of Plan }\end{array}$ \\
\hline C 1 & C 2 & C 3 & C 4 & $\begin{array}{c}C 5=C 3 \\
+C 4\end{array}$ & C 6 & $\begin{array}{c}\text { C 7 = } \\
87.5 \% * \text { C } 6\end{array}$ & C 8 & $\begin{array}{c}C 9=C 7 \\
+C 8\end{array}$ & C 10 \\
\hline 1 & $11^{\text {th }}$ & 132330 & 74374 & 206704 & 950.47 & 831.66 & 331.90 & 1163.56 & 5.63 \\
\hline 2 & $12^{\text {th }}$ & 206704 & 94215 & 300919 & 1163.56 & 1018.12 & 407.67 & 1425.79 & 4.74 \\
\hline 3 & $13^{\text {th }}$ & 300919 & 123900 & 424819 & 1425.79 & 1247.56 & 547.78 & 1795.34 & 4.23 \\
\hline
\end{tabular}

* Includes Capacity addition from Renewable Energy

Capacity \& Manpower at the end of $12^{\text {"m }}$ Plan

\begin{tabular}{|c|c|c|c|c|c|c|}
\hline \multirow[t]{3}{*}{ Sector } & \multicolumn{6}{|c|}{ 12th Plan } \\
\hline & $\begin{array}{c}\text { Capacity at } \\
\text { the } \\
\text { beginning } \\
\text { of } 12 \text { th } \\
\text { Plan }\end{array}$ & $\begin{array}{l}\text { Manpower } \\
\text { at the } \\
\text { beginning of } \\
\text { 12th Plan }\end{array}$ & $\begin{array}{c}\text { Reduced } \\
\text { Manpower due } \\
\text { to Retirement } \\
\text { etc. }\end{array}$ & $\begin{array}{l}\text { Capacity } \\
\text { addition } \\
\text { during 12th } \\
\text { Plan }\end{array}$ & $\begin{array}{l}\text { Additional } \\
\text { Manpower } \\
\text { ramt during } \\
\text { 12th Plan }\end{array}$ & $\begin{array}{l}\text { Manpower at the } \\
\text { end of } 12 \text { th Plan }\end{array}$ \\
\hline & $\mathrm{C1}$ & $\mathrm{C2}$ & $C 3=87.5 \%^{\circ} \mathrm{C} 2$ & $\mathrm{C4}$ & CS & $\mathrm{C} 6=\mathrm{C} 3+\mathrm{CS}$ \\
\hline Thermal & 156533 & 168.90 & 147.79 & 82211 & 55.24 & 203.02 \\
\hline Hydro & 42891 & 74.84 & 65.49 & 9204 & 15.64 & 81.13 \\
\hline Nuclear & 7250 & 16.56 & 14.49 & 2800 & 4.38 & 18.87 \\
\hline Sub-total & 205704 & 260.30 & 227.76 & 94215 & 75.26 & 303.02 \\
\hline Transmission & 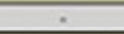 & 37.38 & 32.71 & 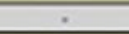 & 8.07 & 40.78 \\
\hline Distribution & - & 865.88 & 757.65 & - & 324.34 & 1081.98 \\
\hline Grand Total & 206704 & 1163.56 & 1018.12 & 94215 & 407.67 & 1425.79 \\
\hline
\end{tabular}

Classroom Training Infrastructure Requirement vs Availability for 12th Plan

(For O\&M of Generating Projects and T\&D system as per CEA norms)

\begin{tabular}{|c|c|c|c|c|c|}
\hline \multirow[b]{2}{*}{$\begin{array}{c}\text { S } \\
\text { No }\end{array}$} & \multirow[b]{2}{*}{ Area } & \multirow[b]{2}{*}{$\begin{array}{c}\text { Training Load/ } \\
\text { Classroom } \\
\text { Infrastructure } \\
\text { required }\end{array}$} & \multicolumn{3}{|c|}{ (Infrastructure in Thousand-Man-Weeks/Year) } \\
\hline & & & $\begin{array}{c}\text { Classroom } \\
\text { Infrastructure } \\
\text { available }\end{array}$ & $\begin{array}{l}\text { Surplus (+) } \\
\text { Deficit (-) }\end{array}$ & $\begin{array}{c}\text { Cost } \\
\text { (Rs Crs) }\end{array}$ \\
\hline \multicolumn{6}{|c|}{ TECHNICAL } \\
\hline \multirow[t]{4}{*}{1} & Thermal (O\&M) & 316.86 & 255.64 & -61.22 & 470.93 \\
\hline & Engineers & 175.07 & 133.66 & -41.42 & 318.58 \\
\hline & Operators & 25.53 & 34.35 & 8.82 & -67.83 \\
\hline & Technicians & 116.26 & 87.64 & -28.62 & 220.18 \\
\hline \multirow[t]{4}{*}{2} & Hydro (O\&M) & 109.50 & 31.72 & -77.79 & 598.35 \\
\hline & Engineers & 82.87 & 18.43 & -64.44 & 495.67 \\
\hline & Operators & 5.92 & 2.75 & -3.17 & 24.39 \\
\hline & Technicians & 20.72 & 10.54 & -10.18 & 78.29 \\
\hline \multirow[t]{5}{*}{3} & Power System & & & & \\
\hline & Transmission & 38.72 & 45.13 & 6.41 & -49.34 \\
\hline & Engineers & 18.56 & 11.14 & -7.42 & 57.07 \\
\hline & Operators & 16.83 & 6.15 & -10.68 & 82.16 \\
\hline & Technicians & 3.33 & 27.84 & 24.51 & -188.57 \\
\hline
\end{tabular}


(Re) Evolution in HR Strategies - Power Sector

The quantum of Skills at various levels required can be considered as per the Pyramid developed by IMaCS for Industry and Construction sector as a general guideline, but may need a revalidation for Power Sector.

The Results - Framework Document (RfD) signed between the Secretary Power \& Minister Power for 2012-13 have agreed to work towards Fresh Capacity Addition of 15956 MW, training of 16225 Persons at NPTI and 132,000 training weeks. These parameters spell the importance of Manpower
training in Power Sector.

\section{Sourcing the Manpower : \\ ITI Adopted by the Project Developers 1 NTPC \\ 2Tata Power \\ 3 Jindal Power \\ 4 Reliance Energy \\ 5 O\&M solutions \\ 15 \\ 4 \\ 5 \\ 2 \\ 1}

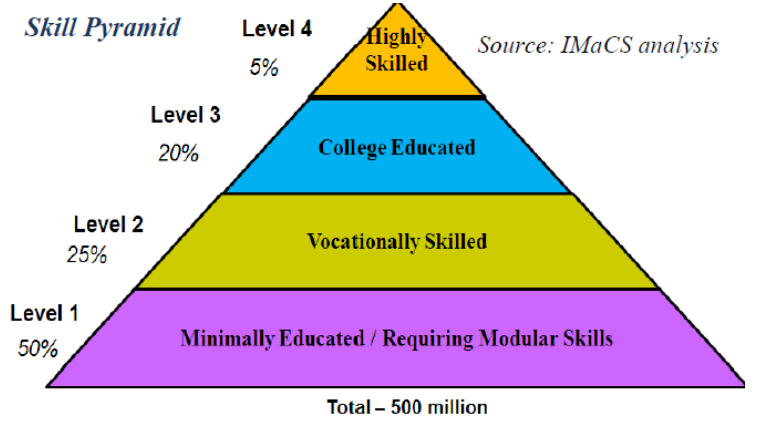

Further, companies should work on changing the work environment through better human resource practices, soft skills training, reducing hierarchical barriers and creating career development maps for the personnel. Experienced HR managers from other sector should be inducted to incorporate best practices from other sectors. With demography in India's favour and this window of young India available for next 15 Years, this is an opportunity for HRM in Power sector to showcase its ability to be a Profit center

\begin{tabular}{|c|c|}
\hline \multicolumn{2}{|c|}{$\begin{array}{l}\text { Incremental Human Resources Requi rement till } \\
\text { 2022: Source Cll and National Skill Development } \\
\text { Initiative }\end{array}$} \\
\hline Mines \& Minerals & $\mid 1,754,881$ \\
\hline Construction & $55,199,568$ \\
\hline Engineering & $1,813,790$ \\
\hline Banking /Insurance & $3,947,139$ \\
\hline Drugs/ Pharma & $1,383,721$ \\
\hline Biotech & $1,209,489$ \\
\hline Healthcare & $20,684,530$ \\
\hline Textiles & $86,545,390$ \\
\hline IT and ITeS & $14,806,299$ \\
\hline Tourism & $12,478,386$ \\
\hline Agro and Food Processing & 169,782 \\
\hline Paper & 57,976 \\
\hline Chemicals and Fertilizers & $1,391,948$ \\
\hline Total & $201,442,899$ \\
\hline
\end{tabular}

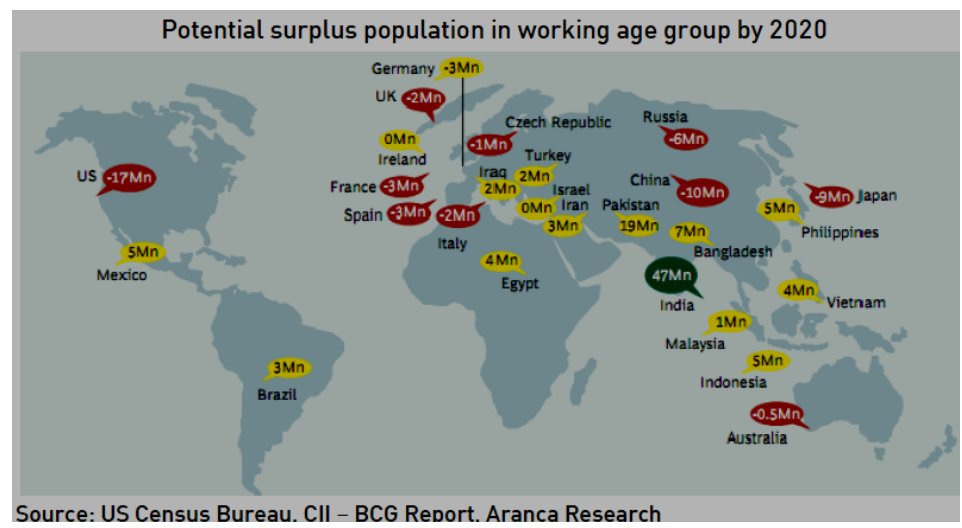

Before Conclusion : Thought Provoking

1. A job profile for a Project Manager for a Coal Fired Power Plant in USA indicates the following requirements.

Quote

\section{"Top candidates will have}

$B S$ degree in Engineering or related technical discipline. Five years of progressively responsible experience in plant operations, maintenance, engineering, and related support activities and a minimum of two years management/supervisory experience is desired.

* Broad knowledge of risks and dangers associated with operating coal fired power plants.

* Broad knowledge of environmental requirements for operating coal fired power plants.

* Thorough knowledge of operation planning and budgeting.

* Working knowledge of power plant operation, including fuel handling, boiler, turbine generator, auxiliary systems, water analysis and treatment.

* Effective managerial and human relations skills.

* Effective communication skills, oral and written.

* Basic understanding of utility economics and the business side of a power company

* Good leadership capabilities to manage and motivate people

* Valid driver's license 
Pass pre-employment drug test, background check, and DMV records check Equal Opportunity Employer who values diversity and inclusion in the workplace."

Unquote

What about the learned wife of a Power Plant Executive at remote site ? Can she be made a useful assets to the Industry /society by making them leant some programs like Animation, IT Cyber safety or similar programs?

\section{Conclusion: (Strategy Evolution)}

1. The HRM can be a profit center and start training as a business thru' a skill center. Skilled manpower is tomorrow's foreign Currency earning source. Skills can be developed with the help of the Industry on the Machines / Technology that is now ready for launch rather than old ITI machines.

2. Take over an ITI if not ready to invest in an ITC or a Skill Center. NSDC provides funds for setting up a Skill Center.

3. Modular Programs, multi skilling, post diploma will help keeping the employees retained longer

4. Helping Skills of Retiring persons to be imparted to the new joiners- sharing the success stories.

5. Vocational Centers can be used for up skilling the retiring personnel on Vocational Programs thru' Vacations at these centers - useful life extension of manpower. Blending Experience \& Education: Seniors in the Industry have older education and techniques but a wealth of experience. Skill Enhancement / Vocational Programs for this group may also be explored (Deputing Seniors on Vacations for Vocational Programs).

6. Utilizing, the Skill sets of the persons nearing retirement after enhancing the skills to match today's technology. - Corporate Level.

7. Inter-department learning at these centers.

8. Experienced manpower can help in Reverse Engineering in Modernization \& Modifications of the Existing Assets at these Skill Centres.

9. Developing Success Stories on Innovation in Maintenance at these Skill Centres.

10. E - learning to be popularized and supported

11. Bridging the awareness gap (Skill Enhancement) at all levels enabling meaningful Energy Consumption, not restricting it to Energy Auditors \& Energy Managers.

12. Skill Up-gradation of Ancillary Industry manpower for Enhanced Role around Power Sector Plants in optimising the Cost of Investments through Technology Up-gradation and Modernisation

13. These Centres can extend hand for more inclusive growth the Power Plant in remote after acquiring land to impart requisite skills to the land evacuees to help absorbing them in Employment.

14. Skill Center with a strong commitment and a Systematic (strategic) planning can help to revive poor people at the evacuated land.

15. Continuous professional enrichment by selling good programs with in your own organisation for your employees.

16. The House wives at remote sites can be made useful professional assests.

17. The Industry's computers or other assets can be used during off time usage.

"Manufacturing Report 2010 CII- BCG Report- Aranca Research

"How to navigate the human age - Harnessing the Rising Power of Technical Professions" - ,Experis Group,

"Human Capital Challenges in the Indian Power Sector",IEMR Report

"Working Group of GoI on Power", Jan 2012 Report

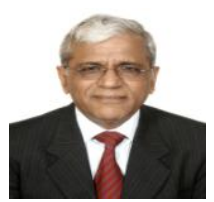

\section{About the Author:}

Y. .P Chawla ; Advisor, Tariff- Jt. Elec. Regu. Commn., National Jt. Secretary IIPE, BE Tech. \& MBA (Fin), PGDPM \& PGDMM from Delhi University. Export Mgmt. from Oxford. Pursuing PhD. in Skill Gaps in Power Sector, Over 4 decades of Experience in diversified sectors covering Energy including Solar \& other Renewable Energy, (Ex. BHEL), Water Sector, Agriculture, Infrastructure. Widely travelled in India \& abroad including some Foreign Postings. Because of these postings got opportunities to get an holistic approach of Power Sector in Manufacturing, Generation, Transmission, Distribution - Coal Fired, Combined Cycle Gas, Hydel, and Solar projects etc. later and now have a feel of the regulation as a petitioner and now as Advisor Tariff JERC. Have written papers on Diversified subjects as under (available on web) 


\section{Skill Related}

1. ContoursofReformsinEngineeringEducationforbetterEmployabilityhttp://www.scribd.com/doc/10566950 $\underline{2}$

2. EnhancingSkillsandFasterGenerationofEmploymenttheroleofEngineers\&Technocratshttp://www.scribd.c om/doc/105687427/Enhancing-Skills-and-Faster-Generation-of-Employment-\%E2\%80\%93-the-role-ofEngineers-Technocrats

3. Sustainable Development - Role of Engineering Managers and Technologistshttp://www.docstoc.com/docs/129319319/Sustainable-Development---Role-ofEngineering-Managers-and-Technologists

4. Maintenance-Management-during-Economic-Slow-Down http://www.docstoc.com/docs/129319145/Maintenance-Management-during-Economic-Slow-Down

5. Approach to Zero Breakdown- A Challenge of Multi Management Aspectshttp://www.scribd.com/doc/39036672/Approach-to-Zero-Breakdown-\%E2\%80\%93-AChallenge-of-Multi-Management-Aspects ; http://www.scribd.com/doc/105687410 http://www.docstoc.com/docs/129318992/Approach-to-Zero-Breakdown

6. Business Excellence through Human Asset Management - Building Competence

\section{Power Sector Related}

7. Power Sector Project Management Challenges http://www.ptlenterprise.com/power_sector.html

8. Coal Quality - A New Paradigm http://www.scribd.com/doc/39037151/Coal-Quality-A-new-Paradigm http://www.scribd.com/doc/105687422/Coal-Quality

9. RenewableEnergyforInclusiveGrowthRoleofNGOshttp://www.iipe.co.in/journal/aug10/Renewable\%20E nergy\%20for\%20Inclusive\%20Growth.pdf

10. India'sSustainableGreenGrowthRuralSectorthruRenewableshttp://www.iipe.co.in/journal/jun09/ISG.pdf ; http://www.scribd.com/doc/105687447/India-s-Sustainable-Green-Growth-Rural-Sector-ThruRenewable-YP-Chawla ; http://www.docstoc.com/docs/129319141/India's-Sustainable-Green-Growth--Rural-Sector-thru-Renewables

11. Integration of Solar Power \& Hydro

\section{Steel Sector Related}

12. Iron Ore Beneficiation: Challenges to Iron \& Steel Industryhttp://www.scribd.com/doc/39037668/1-0BasePaperYPChawlahttp://www.scribd.com/doc/75444520/Beneficiationofhttp://www.scribd.com/doc/1 05687395/1-0-Iron-Ore-Beneficiation-Base-Paper-YP-Chawla

13. WasteManagementinSteelPlants,BasePaper:YPChawlaCEOZoomDevelopersPLtdhttp://www.iipe.co.in/s eminar/IIPE_Final_1-192.pdf

14. ChallengesMaintenanceManagementofAssetsduringtheCurrentEconomicMeltdownhttp://www.scribd.co $\mathrm{m} /$ doc/105687458/Maintenance-Management-During-Economic-Breakdown-32-41

15. Waste-Mangement-in-Steel-Sectorhttp://www.docstoc.com/docs/129319647/Waste-Mangement-in-SteelSector

16. Israeli advanced water technologies- Sharing Tahal experience with India - Eli Barak Director Marketing, Asia Operations \& YP Chawla Marketing Director - India Operations, Tahal Consulting Engineers Ltd.http://www.indiacoreevents.in/bulletin/papers-wi4/mr-eli-barak-israeli-advanced-watertechnologies-sharing-tahal-experience-with-india.pdf

17. Carbon Abetment 